\title{
Study of the prevalence of uveitis in a tertiary ophthalmology hospital in Teresina, Piauí, Brazil
}

\author{
Estudo da prevalência das uveítes em hospital \\ oftalmológico terciário em Teresina, Piauí, Brasil
}

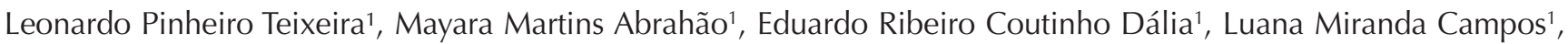
João Jorge Nassaralla Junior², Vitor Cortizo Da Fonseca ${ }^{3}$

\begin{abstract}
Objective: To analyze the prevalence of uveitis in patients treated at a tertiary ophthalmic service in Teresina, Piaui State, Brazil. Methods: This was a retrospective study based on medical records of patients treated at this service. Sex, age, origin, underlying diseases, anatomical diagnosis, clinical aspects and progression time were described. Results: 403 records were included, noting that 3.2 out of every 1,000 patients treated at the service had uveitis. The average age of patients was 42 years old, with both sexes (50.6\% females and $49.4 \%$ males) affected similarly, and with $61.5 \%$ coming from the state capital, Teresina. The most common underlying disease was toxoplasmosis, followed by idiopathic uveitis with ocular manifestations only. As to the anatomical classification, $49.6 \%$ of them were posterior and only $3.5 \%$ were intermediate. Regarding the clinical aspects, $64 \%$ were granulomatous, $24.8 \%$ non-granulomatous, and $11.2 \%$ were not classifiable. According to the clinical progression, $41.4 \%$ were acute, followed by $30.8 \%$ chronic, $14.4 \%$ recurrent cases, and $13.4 \%$ of patients did not return for medical care. Conclusion: we found that for every 1,000 patients treated at the service, 3.2 had uveitis, with toxoplasmosis itself found to be an important source of uveitis.
\end{abstract}

Keywords: Toxoplasmosis; Idiopathic uveitis; Uveitis/classification

\section{ReSUMO}

Objetivo: analisar a prevalência das uveítes em pacientes atendidos em um serviço oftalmológico terciário em Teresina, Piauí. Métodos: estudo retrospectivo baseado em prontuários de pacientes atendidos nesse serviço. Foram descritos: gênero, faixa etária, procedência, doença de base, diagnóstico anatômico, aspecto clínico e tempo de evolução. Resultados: foram incluídos 403 prontuários constatando-se que a cada 1000 pacientes atendidos neste serviço, 3,2 tinham uveíte. A idade média dos pacientes foi de 42 anos, tanto o gênero feminino (50,6\%) quanto o gênero masculino $(49,4 \%)$ foram acometidos similarmente, com $61,5 \%$ dos pacientes provenientes da capital. A doença de base mais frequente foi a toxoplasmose, seguida das uveítes idiopáticas apenas com manifestações oculares. Quanto à classificação anatômica, $49,6 \%$ foram posteriores e 3,5\% foram intermediárias. Em relação ao aspecto clínico, $64 \%$ foram granulomatosas, 24,8\% não-granulomatosas e 11,2\% não foram classificáveis. Segundo a evolução clínica, 41,4\% foram agudas, seguidas de $30,8 \%$ crônicas, $14,4 \%$ recorrentes e em $13,4 \%$ os pacientes não foi feito o acompanhamento. Conclusão: pudemos constatar que para cada 1000 pacientes atendidos neste serviço 3,2 tinham uveíte, apresentando-se a toxoplasmose como importante fonte de uveíte neste serviço.

Descritores: Toxoplasmose ocular; Uveíte idiopática; Uveíte/classificação

\footnotetext{
1 Instituto de Olhos de Goiânia, Goiânia, GO, Brasil.

2 Departamento de Retina e Vítreo, Instituto de Olhos de Goiânia, Goiânia, GO, Brasil.

${ }^{3}$ Hospital de Olhos Francisco Vilar, Teresina, PI, Brasil.

The authors declare no conflicts of interests.

Received for publication 31/07/2015 - Accepted for publication 19/03/2016.
} 


\section{INTRODUCTION}

$\mathbf{U}$ veitis is the inflammation of the uveal tract, consisting of the iris, ciliary body and choroid, and may affect secondarily other structures such as the cornea, sclera, vitreous, retina and optic nerve. It can be a systemic manifestation of infectious diseases, rheumatic diseases, diseases of unknown etiology, or occur in the absence of any detectable illness. Complications which can lead to blindness, such as cataract, glaucoma and retinal detachment may be associated to uveitis, with cataract being the most common complication ${ }^{1}$.

The SUN (Standardization of Uveitis Nomenclature) Working Group Descriptors of Uveitis ${ }^{2}$, in order to start a process of standardization of clinical data in the field of uveitis, adapted the classification created by the International Uveitis Study Group. ${ }^{3}$ This classification helped to standardize the nomenclature and understand the factors related to the natural history of the various types of uveitis involved, among other factors, anatomical, clinical and evolutionary aspects. ${ }^{4}$

Due to the wide variety of causes of uveitis, it is common the influence of factors such as age, gender, race, geographic location, social factors, immunological factors, among others. Given the abundance of diseases that can originate them, it is important to undertake studies of prevalence. They contribute to preventive planning, diagnostic and therapeutic of the most frequent clinical entities.

In the absence of a similar study in Piauí, and considering that Teresina has been for many years standing out in the middle northern Brazil as a reference point in medicine and health, the present study aims to analyze the prevalence of uveitis in patients in a tertiary ophthalmic service.

\section{Methods}

A retrospective cross-sectional descriptive epidemiological study was conducted based on the query to electronic records of patients seen at Hospital de Olhos Francisco Vilar (Teresina, Piauí) during the period from January $1^{\text {st }}, 2006$ to December $31^{\text {st }}, 2011$.

A search strategy about the electronic medical records from the hospital was followed, searching for keywords including uveitis, and synonyms sucha as iritis and iridocyclitis, besides the search for underlying diseases (toxoplasmosis, toxocariasis, tuberculosis, Reiter's syndrome, sarcoidosis, syphilis, rheumatoid arthritis, juvenile rheumatoid/idiopathic arthritis, acquired immunodeficiency syndrome - AIDS, Behcet's disease, ankylosing spondylitis, systemic lupus erythematosus, cytomegalovirus, herpes simplex, Vogh-Koyanagi-Harada syndrome, Fuchs' heterochromic iridocyclitis) that could lead to the same, taking care to insert the records only once in the statistics. The following data was described: gender, age, origin, underlying disease and classifications related to the position, development and clinical aspect. Each uveitis found was separated according to their underlying disease, with idiopathic and other groups also being created. The Group Idiopathic was used to discriminate against the uveitis presenting only ocular manifestations without systemic changes and in the complementary examinations, and the Group Others was used to locate diseases occurring only once and which were not in the research protocol.
The diagnosis was established based on complete ophthalmological consultations consisting of the clinical history of the patient (history of present disease, past pathological history) and eye exam (measurement of visual acuity, ectoscopy, biomicroscopy of the anterior and posterior segments, ophthalmoscopy), until the subsequent request for complementary, general and/or eye exams, according to the need, for confirmation of the diagnosis. The patients who didn't bring the complementary exams and did not continue the assessment were excluded, as well as the patients with uveitis triggered shortly after surgery or trauma, so we don't know for sure the amount of patients with possible uveitis excluded from the study, because some abandoned the hospital follow up before the diagnostic hypothesis had been proven. Uveitis with signs and symptoms of activity during consultation and follow up were included in the statistics. They were considered to be active when they presented cells and flare in the anterior chamber, fine or coarse keratic precipitates (KPs), fibrin on the corneal endothelium, hypopyon, iris nodules, anterior or posterior synechiae, vitreous cells, snowballs, snowbanks, inflammatory lesions in the retina or choroid, vasculitis associated to symptoms such as pain, red eye, photophobia, decreased visual acuity, floaters, perikeratic or limbic hyperemia. A uveitis expert assessed the pre-selected medical records to make sure about the diagnostic hypothesis.

The classification used followed the criteria set out by the International Uveitis Study Group ${ }^{3}$ adapted by SUN ${ }^{2}$. Therefore, according to the anatomy, uveitis was considered anterior when the primary inflammation site was in the anterior chamber (iritis, anterior cyclitis and iridocyclitis); intermediate when the primary site affected the vitreous body (pars planitis, posterior cyclitis, hyalitis); posterior when affected primarily the choroid or retina (focal, multifocal or diffuse choroid, chorioretinitis, retinochoroiditis, retinitis and neuroretinitis); and panuveitis when affected the anterior chamber, vitreous and choroid or retina concurrently.

Another criteria adopted for the classification of uveitis was its clinical course, based on the development of the disease. Thus, uveitis is characterized as acute when with sudden onset and limited duration; as recurrent when with repeated episodes separated by periods of inactivity when untreated and lasting more than 3 months; and as chronic or long-term uveitis when persistent with relapse in less than 3 months after discontinuation of treatment. ${ }^{5}$

Finally, uveitis is classified according to the clinical aspect in granulomatous and non-granulomatous uveitis. Granulomatous were the ones presenting coarse keratic precipitates as mutton fat, iris nodules, or those with the lesion similar to a granuloma. The non-granulomatous were the uveitis with fine keratic precipitates and without lesion or granulomatous aspect.

The results collected from the forms were submitted to descriptive statistical treatment by means of percentages, and all data was discriminated by charts and graphs. All calculation was performed using the statistical program SPSS version 17.0 and the Microsoft Office Excel version 2010.

The study was conducted in accordance with resolution 196/96 of Conselho Nacional de Saúde, which relates to the 
regulatory guidelines and norms for research involving humans, and approved by the Research Ethics Committee (CEP) of Faculdade NOVAFAPI under the protocol number 0297.0.043.000-11.

\section{Results}

A total of 403 patients with uveitis attended at Hospital de Olhos Francisco Vilar during the 6 years established by the study was included. During this period, 127,816 patients were attended, and 3.2 in every 1,000 patients had uveitis. The age of patients during the beginning of the signs and symptoms of uveitis ranged between 4 and 90 years old, with an average of 42 years, distributed as follows: between 0 and 12 years: 13 patients $(3.2 \%)$, between 13 and 18 years: 20 patients $(5 \%)$, between 19 and 60 years: 290 patients $(72 \%)$, >60 years: 80 patients $(19.8 \%)$, among them 199 (49.4\%) were men and 204 $(50.6 \%)$ were women. We also observed that 248 patients $(61.5 \%)$ were from the capital of the State of Piauí, 110 from the countryside in the State of Piaui $(27.3 \%)$, and 45 were from another State (11.2\%) (Chart 1).

The etiologies of uveitis could not be identifiedi 164 $(40.7 \%)$ of medical records selected. Among the underlying diseases diagnosed, the most frequent was toxoplasmosis, with 167 cases $(41.4 \%)$, followed by tuberculosis $12(3 \%)$, ankylosing
Chart 1

Clinical and epidemiological profile of patients with uveitis

\begin{tabular}{llll}
\hline & & $\mathbf{N}^{\mathbf{0}}$ & $\mathbf{\%}$ \\
\hline \multirow{2}{*}{ Gender } & Male & 199 & \\
& Femmale & 204 & 59.4 \\
& Age group (years) & & \\
& 0 a 12 years & 13 & 3.2 \\
& 13 a 18 years & 20 & 5.0 \\
& 19 a 60 years & 290 & 80 \\
& $>60$ years & 72,0 & 19.8 \\
\hline \multirow{2}{*}{ Origin } & Capital & 248 & 61.5 \\
& Countryside & 110 & 27.3 \\
& Another State & 45 & 11.2 \\
\hline Total & & $\mathbf{4 0 3}$ & $\mathbf{1 0 0 . 0}$ \\
\hline
\end{tabular}

spondylitis $9(2.2 \%)$, Vogt-Koyanagi-Harada syndrome 8 (2\%), toxocariasis $7(1.7 \%)$, syphilis $5(1.2 \%)$, juvenile idiopathic arthritis $4(1.0 \%)$, rheumatoid arthritis $4(1.0 \%)$, herpes simplex $(0.7 \%)$, Fuchs' heterochromic iridocyclitis $3(0.7 \%)$, cytomegalovirus $2(0.5 \%)$ and systemic lupus erythematosus 1 $(0.3 \%)$. In addition, 12 medical records $(3 \%)$ were in the Group Other (Graph 1).

\section{Gráph1}

\section{Distribution of Basic Diseases Patients with Uveitis Teresina - PI , January 2006 - December 2011}

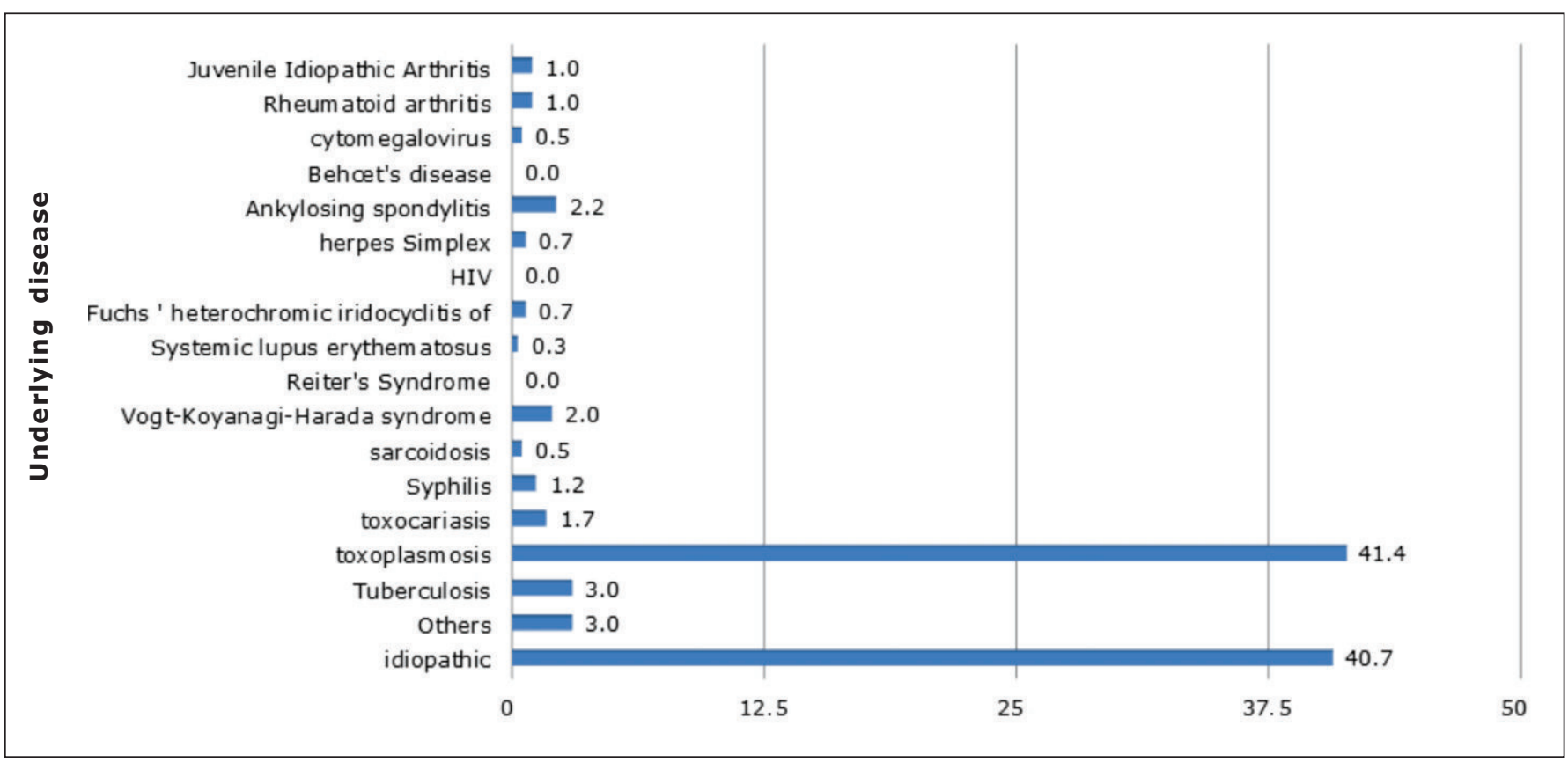

Regarding the anatomical classification, a greater frequency of posterior uveitis was shown in 200 cases $(49.6 \%)$, of which toxoplasmosis stood out with 157 cases $(78.5 \%)$. The anterior uveitis was in 145 medical records $(36.0 \%)$, followed by the panuveitis $44(10.9 \%)$ and intermediate uveitis $14(3.5 \%)$, especially in the last three parameters mentioned, with idiopathic uveitis with only ocular manifestations with 111, 18 and 11 cases, respectively (Chart 2).

The clinical development in chart 3 shows that 167 of uveitis (41.4\%) were acute, 124 chronic $(30.8 \%), 58$ recurrent $(14.4 \%)$ and 54 patients $(13.4 \%)$ did not have complete follow-up, being not possible to study the development. 
Chart 2

Underlying disease by anatomical classification

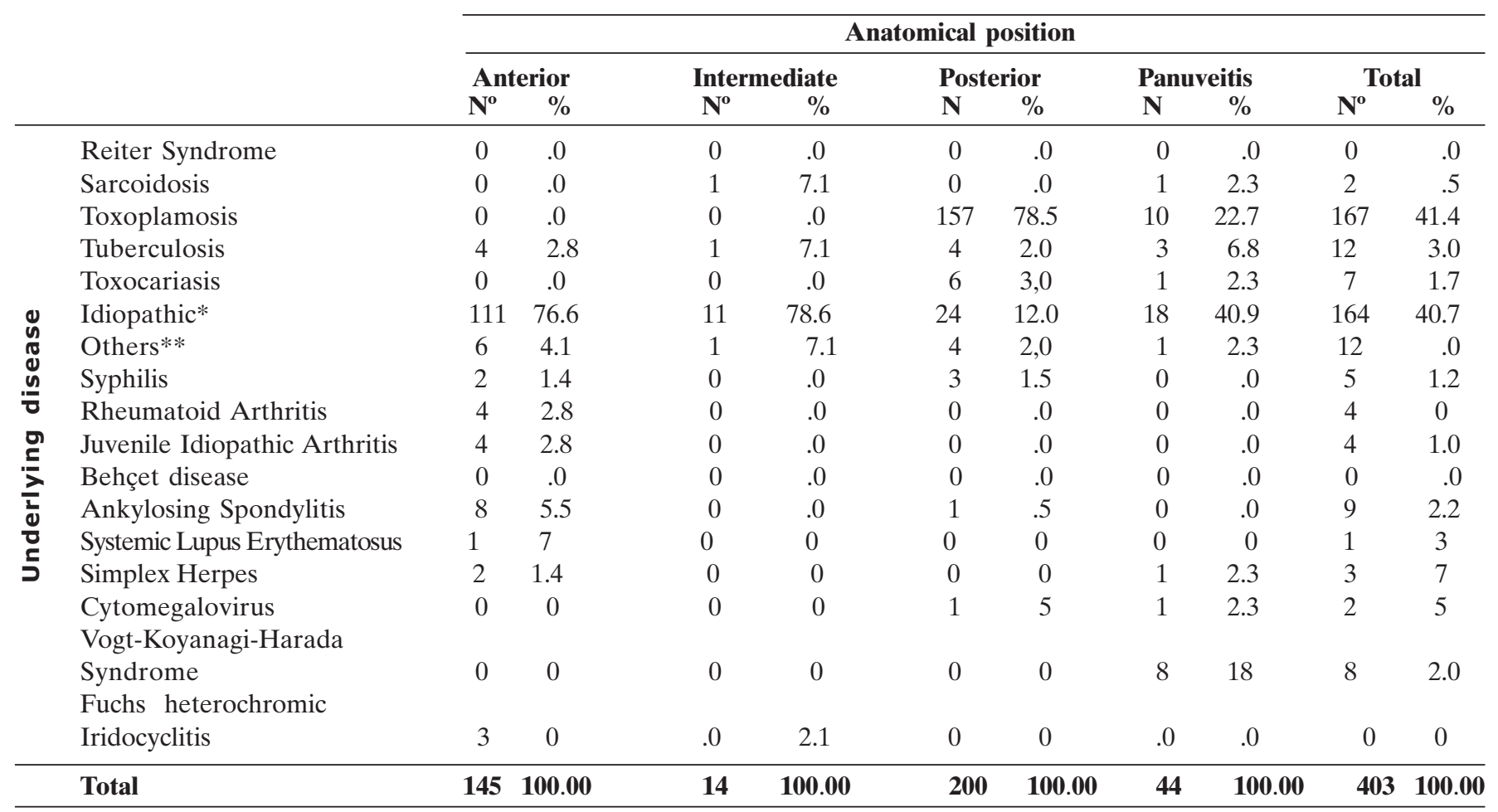

diopathic*: idiopathic uveitis with only ocular manifestationsOthers**: uveitis appearing only once: Sjogren's syndrome, psoriasis, Posner Schlossman syndrome, Fibromyalgia, CINCA Syndrome, Shingles, Sympathetic Ophthalmia, Reactive Arthritis, Serpiginous Choroiditis, Crohn's Disease, Birdshot Retinochoroidopathy, Kawasaki Disease

\section{Chart 3}

Underlying disease by clinical development

\begin{tabular}{|c|c|c|c|c|c|c|c|c|c|c|c|}
\hline & \multicolumn{10}{|c|}{ Clinical development } \\
\hline & & \multicolumn{2}{|c|}{ Acute } & \multicolumn{2}{|c|}{ Chronic } & \multicolumn{2}{|c|}{ Recurrent } & \multicolumn{2}{|c|}{$\begin{array}{l}\text { Did not have } \\
\text { follow-up }\end{array}$} & \multicolumn{2}{|c|}{ Total } \\
\hline & & $\mathbf{N}^{\mathbf{o}}$ & $\%$ & $\mathbf{N}^{\mathbf{o}}$ & $\%$ & $\mathbf{N}^{\mathbf{o}}$ & $\%$ & $\mathbf{N}^{\mathbf{o}}$ & $\%$ & $\mathbf{N}^{\mathbf{o}}$ & $\%$ \\
\hline \multirow{14}{*}{ 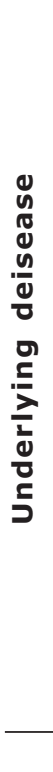 } & Reiter's Syndrome & 0 & .0 & 0 & .0 & 0 & .0 & 0 & .0 & 0 & .0 \\
\hline & Sarcoidosis & 0 & .0 & 0 & .0 & 2 & 3.5 & 0 & .0 & 2 & .5 \\
\hline & Toxoplamosis & 98 & 58.7 & 39 & 31.5 & 10 & 17.2 & 20 & 37,0 & 167 & 41.4 \\
\hline & Idiopathic* & 59 & 35.3 & 55 & 44.4 & 21 & 36.2 & 29 & 53.7 & 164 & 40.7 \\
\hline & Others** & 2 & 1,2 & 7 & 5.6 & 3 & 5.2 & 0 & .0 & 12 & 3.0 \\
\hline & Syphilis & 1 & .6 & 3 & 2.4 & 0 & .0 & 1 & 1.9 & 5 & 1.2 \\
\hline & Rheumatoid Arthritis & 1 & .6 & 0 & .0 & 3 & 5.2 & 0 & .0 & 4 & 1.0 \\
\hline & Juvenile idiopathic arthritis & 0 & .0 & 0 & .0 & 4 & 6.9 & 0 & .0 & 4 & 1.0 \\
\hline & Behcet disease & 0 & .0 & 0 & .0 & 0 & .0 & 0 & .0 & 0 & .0 \\
\hline & Vogt-Koyanagi- & & & & & & & & & & \\
\hline & Harada Syndrome & 0 & 0 & 4 & 3.2 & 3 & 5.2 & 1 & 1.9 & 8 & 2.0 \\
\hline & Fuchs' heterochromic & & & & & & & & & & \\
\hline & Iridocyclitis & 2 & 2.2 & 1 & 8 & 0 & 0 & 0 & 0 & 3 & 7 \\
\hline & Total & 167 & 100.00 & 124 & 100.00 & 58 & 100.00 & 54 & 100.00 & 403 & 100.00 \\
\hline
\end{tabular}

Source: Electronic medical records of Hospital de Olhos Francisco VilarIdiopathic*: idiopathic uveitis with only ocular manifestationsOthers**: uveitis appearing only once: Sjogren's syndrome, psoriasis, Posner Schlossman syndrome, Fibromyalgia, CINCA Syndrome, Shingles, Sympathetic Ophthalmia, Reactive Arthritis, Serpiginous Choroiditis, Crohn's Disease, Birdshot Retinochoroidopathy, Kawasaki Disease 
Finally, according to the clinical aspect, 258 medical records (64.0\%) had granulomatous aspect, among these $163(63.2 \%)$ were due to toxoplasmosis and $59(22.9 \%)$ due to idiopathic uveitis with only eye manifestations. A non-granulomatous aspect was observed in 100 medical records $(24.8 \%)$, among which 70 $(70 \%)$ were related to rheumatologic diseases. Of the total number of medical records, in 45 cases $(11.2 \%)$ the classification was not possible due to insufficient data (Chart 4).

Chart 4

Underlying Disease by Clinical Aspect. Teresina (PI), January 2006 - December 2011

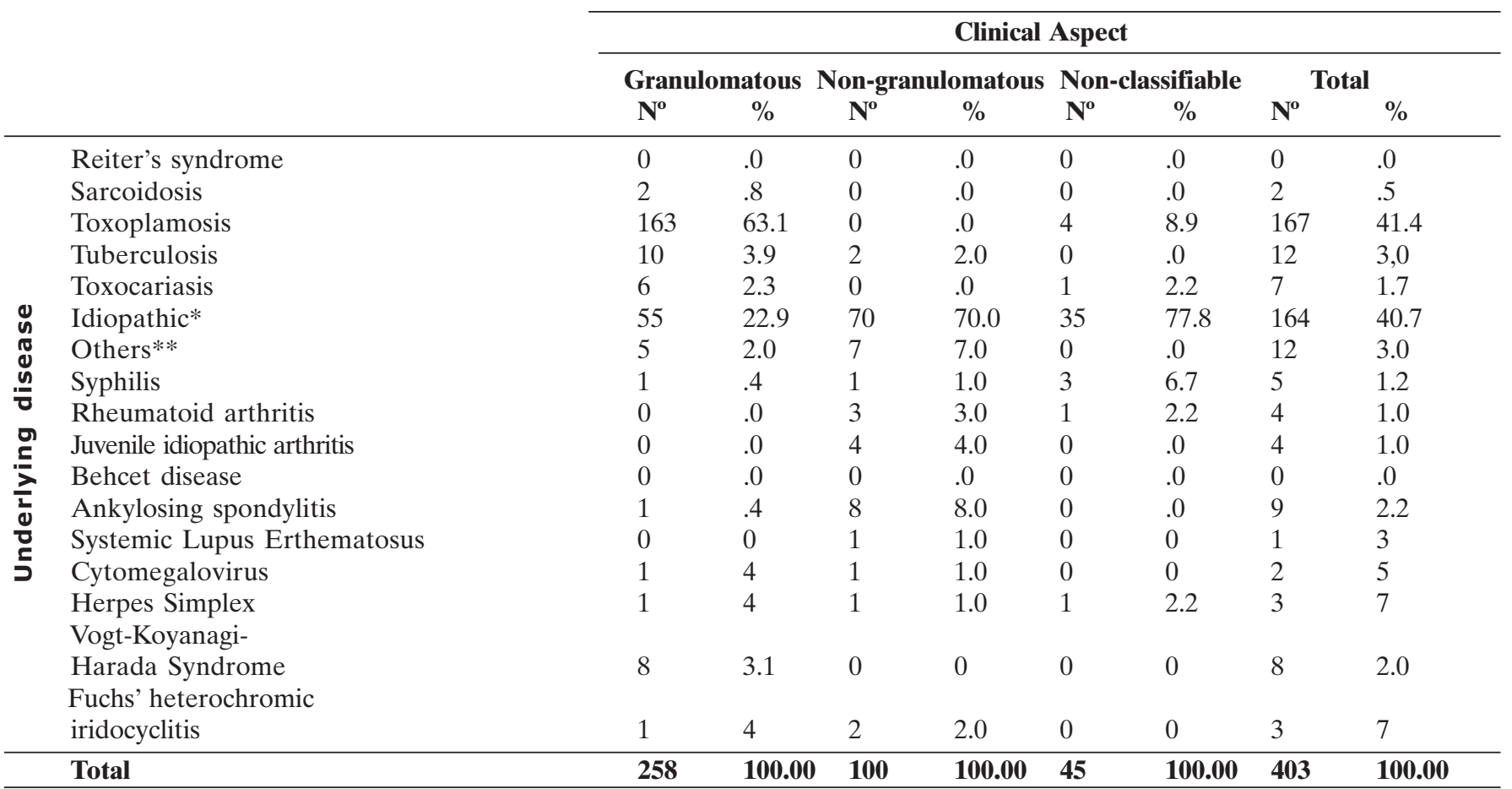

Source: Electronic medical records of Hospital de Olhos Francisco VilarIdiopathic*: idiopathic uveitis with only ocular manifestationsOthers**: uveitis appearing only once: Sjogren's syndrome, psoriasis, Posner Schlossman syndrome, Fibromyalgia, CINCA Syndrome, Shingles, Sympathetic Ophthalmia, Reactive Arthritis, Serpiginous Choroiditis, Crohn's Disease, Birdshot Retinochoroidopathy, Kawasaki Disease

\section{DiscussiOn}

The present study examined the prevalence of uveitis in patients treated in a reference ophthalmic hospital in Teresina PI during 6 years. "Epidemiological studies in uveitis are important, since demographic factors such as age, gender, race, socio-economic aspects, occupation, lifestyle, and geographic origin can influence. The world literature reports large geographical variations in the etiology of uveitis. "6

Because it is a retrospective study in which exposure and disease are measured after the same have already occurred, the patients' records ${ }^{7}$ showed the loss of some patients. However, it did not invalidate our research because we could have a large sample, this loss was minimal and we had the opportunity to diagnose in our region the presence of various infectious or non-infectious diseases of systemic or local distribution, some including important relevance to public health in our country. We must highlight that uveitis can develop with various complications that can lead even to blindness, limiting the population affected. The study "Analysis of the quality of life of patients with uveitis of infectious and non-infectious causes by questionnaire NEI-VFQ-25" performed by Mello et al. ${ }^{8}$ pointed out that most of the patients who have or have had uveitis present a high rate of morbidity, being it by the activity of the diseases, refraction errors or cataracts triggered by the sequelae of them. This shows the need for a rigorous planning for a better approach of patients with uveitis, taking into consideration not only the therapeutic aspects but also the social and economic aspects.

According to Kanski ${ }^{9}$ the patient's age and gender at the time of onset of the disease are very important factors because certain types of uveitis occur in a specific age group, while others can happen at any age, in addition to present in a higher or lower amount at a given gender, helping guide the diagnosis. In general, due to the wide variety of diseases and the more frequent ones affect both genders, both women (50.6\%) and men $(49.4 \%)$ were affected in a similar way, and although all age groups have been affected, we observed that as well as in literature, uveitis ${ }^{10}$ was less frequent during childhood (from 0 to 12 years old), and adults (from 19 to 60 years old) were responsible for the largest portion of the cases.

We can observe in the graph 1 that toxoplasmosis was the most prevalent disease, with $41.4 \%$ of uveitis cases, being also the main cause of posterior uveitis, as shown in chart 2, corroborating with data from the literature showing this as the most common cause of retinochoroiditis in immunocompetent patients in the world. $5,6,9,11-14$

Right after that is idiopathic uveitis only with ocular manifestations, being presented in a large number of cases and important sources of anterior uveitis $(76.6 \%)$. Uveitis associated 
to systemic rheumatic diseases had a total of $5 \%$ of the sample, with ankylosing spondylitis being the most diagnosed with only 9 cases. In Europe the disease proved to be the main cause of anterior uveitis among the diagnosed uveitis ${ }^{14}$, and according to several other sources the idiopathic uveitis is the most common form of inflammation in the anterior segment, with about half of patients showing only eye changes, about $30 \%$ showing iridocyclitis with HLA-B27 positive, and the remainder being associated to systemic diseases such as ankylosing spondylitis or juvenile idiopathic arthritis. ${ }^{11,14-16}$ In our sample the small amount of said uveitis contrasts the world literature; this may be due to the character, which in the vast majority of the time is self-limited and improve only with instillation of corticosteroid eyedrops, influencing patients not to go to the subsequent appointments with the appropriate follow-up and diagnostic certification.

The rest of the uveitis described, including tuberculosis, toxocariasis, syphilis, herpes simplex, cytomegalovirus are important causes of uveitis ${ }^{17,18}$, whose treatment is successful when diagnosed early and treated appropriately. However, we can observe that due to poor adherence of therapy, sometimes these processes end up becoming chronic and causing irreversible damage. In our sample, although we have some AIDS-positive patients, we haven't had any cases of patients with uveitis specifically by the AIDS virus. The samples were distributed among opportunistic infections such as tuberculosis, syphilis and herpes simplex once progressive and severely immunocompromised patients increase the susceptibility to various viral, fungal and parasitic infections. ${ }^{11}$

It can also be observed in chart 4 that the majority (64.0\%) of uveitis had granulomatous aspect. This fact was influenced by the high natural prevalence of infectious diseases, with a predilection for the posterior chamber. Posterior uveitis is usually classified as granulomatous because this process has a predilection for the posterior uvea, although it can affect any part of the uveal tract. ${ }^{19}$

According to the clinical development, although acute uveitis has been more prevalent 167 (41.4\%), many cases were chronicle with 124 cases $(30.8 \%)$, recurrent with 58 cases $(14.4 \%)$ and in 54 cases $(13.4 \%)$ it was not possible to classify the development. These patients were enrolled in the study, as they had the follow-up in time for the diagnosis (with clinical examination, and complementary general and/or eye examinations), but not for the classification.

\section{CONCLUSION}

This study found a prevalence of 3.2 cases of uveitis for every 1,000 patients treated, showing us the relative frequency of uveitis found in this service, among which toxoplasmosis was the most prevalent followed by idiopathic uveitis with only ocular manifestations. Numerous other infectious and non-infectious causes with important social impact as tuberculosis, syphilis, and ankylosing spondylitis were also identified.

We could also observe that, in general, the majority of uveitis had a natural tendency to granulomatous aspect with posterior location. However, these ratings are not independent, and are influenced by the underlying disease that triggered the uveitis.

\section{REFERENCES}

1. Höfling-Lima AL, Moeller CT, Freitas D, Martins EM. Manual de condutas em Oftalmologia. São Paulo: Atheneu. 2008. 1249p.

2. Jabs DA, Nussenblatt RB, Rosenbaum JT; Standardization of Uveitis Nomenclature (SUN) Working Group. Standardization of uveitis nomenclature for reporting clinical data. Results of the First International Workshop. Am J Ophthalmol. 2005;140(3):509-16. Review.

3. Bloch-Michel E, Nussenblatt RB. International Uveitis Study Group recommendations for the evaluation of intraocular inflammatory disease. Am J Ophthalmol. 1987;103(2):234-5.

4. Dimantas MA, Lowder C, Muccioli C. Uveítes anteriores associadas a doenças sistêmicas. Arq Bras Oftalmol. 2003; 66(2):235-8.

5. Nussenblatt, RB, Whitcup SM. Uveitis, fundamental and clinical practice. $4^{\mathrm{a}}$ ed. Rio de Janeiro: Elsevier; 2010. 480p.

6. Gouveia EB, Yamamoto JH, Abdala M, Hirata CE, Kubo P, Olivalves E. Causas das uveítes em serviço terciário em São Paulo, Brasil. Arq Bras Oftalmol. 2004; 67(1):139-45.

7. Medronho R, Bloch KV, Luiz RR, Werneck, GL, editores. Epidemiologia. 2a ed. São Paulo: Atheneu; 2009. 685p.

8. Mello PR, Roma AC, Moraes Junior HV. Análise da qualidade de vida de portadores de uveítes de causas infecciosas e não infecciosas pelo questionário NEI-VFQ-25. Arq Bras Oftalmol. 2008; 71(6):847-54.

9. Kanski JJ. Oftalmologia clínica: uma abordagem sistemática. 6a ed. Rio de Janeiro: Elsevier; 2008. 931p.

10. Edelsten C, Reddy MA, Stanford MR, Graham EM. Visual loss associated with pediatric uveitis in english primary and referral centers. Am J Ophthalmol. 2003; 135(5):676-80.

11. Pavan-Langston D. Manual de oftalmologia: diagnóstico e tratamento. 4 ed. Rio de Janeiro: Medsi, 2001. 592p.

12. Oréfice F. Uveíte clínica e cirúrgica: texto e atlas. $2^{\text {a }}$ ed. Rio de Janeiro: Cultura Médica, 2005. 1480p.

13 - Gehlen ML, Dabul VM, Obara SS, Grebos SP, Moreira CA. Incidência e etiologia de uveítes em Curitiba. Arq Bras Oftalmol. 1999; 62(5):622-6.

14. Paivonsalo-Hietanen $\mathrm{T}$, Touminen J, Vaahtoranta-Lehtone $\mathrm{H}$, Saari KM. Incidence and prevalence of different uveitis entities in Finland. Acta Ophthalmol Scand. 1997; 75(1):76-81.

15. Skare TL, Silva TQ, Pastro PC. Uveíte das espondiloartropatias: prevalência e relação com doença articular. Arq Bras Oftalmol. 2007;70(5):827-30.

16. Mikkila H, Seppala I, Leirisalo-Repo M, Immonen I, Karma A. The etiology of uveitis: The role of infections with special reference to Lyme borreliosis. Acta Ophthalmol Scand. 1997; 75(6):716-9.

17. Benezra D, Cohen E, Maftzir G. Uveitis in children and adolescents. Br J Ophtalmol. 2005;89(4):444-8.

18. Babu RB, Sudharshan S, Kumarasamy N, Therese L, Biswas J. Ocular tuberculosis in acquired immunodeficiency syndrome. Am J Ophthalmol. 2006;142(3):413-8.

19. Vaughan D, Taylor A. Oftalmologia geral. $3^{\text {a }}$ ed. São Paulo: Atheneu; 1990. 438p.

\section{Corresponding author:}

Leonardo Pinheiro Teixeira

E-mail: leonardop_007@msn.com 


\section{APPENDIX - Form for Data Collection}

Form number:

01 - age:

02 - Gender:

( ) $\mathrm{M}$

( ) F

03 - Origin:

( ) Capital of PI

( ) Countryside of PI

( ) another State

04 - Underlying disease:

( ) Reiter's syndrome

( ) Rheumatoid Arthritis

( ) Juvenile Rheumatoid Arthritis

( ) AIDS

( ) Cytomegalovirus

( ) Behcet disease

( ) Ankylosing spondylitis

( ) Fuchs' heterochromic iridocyclitis

( ) Herpes Simplex

( ) Systemic Lupus Erthematosus

( ) Syphilis

( ) Vogt-Koyanagi-Harada Syndrome

( ) Sarcoidosis

( ) Toxoplasmosis

( ) Tuberculosis

( ) Toxocariasis

( ) SDD

( ) other

05 - Classification of uveitis regarding the anatomical position:

( ) anterior ( ) intermediate ( ) posterior ( ) difuse

06 - Classification of uveitis regarding the development:

( ) acute ( ) chronic ( ) recurrent ( ) Without follow-up

07 - Classification of uveitis regarding the clinical aspect:

( ) granulomatous ( ) non-granulomatous ( ) Not possible to identify 